\title{
Hamare Keral Mein Ek Kahavat Hai...: Remakes in Cinema and the Burdens on the "Translated Text"
}

\author{
Ratheesh Radhakrishnan
}

\section{(2) OpenEdition}

\section{Journals}

\section{Electronic version}

URL: http://journals.openedition.org/transtexts/189

DOI: $10.4000 /$ transtexts. 189

ISSN: 2105-2549

Publisher

Gregory B. Lee

\section{Printed version}

Date of publication: 1 May 2006

Number of pages: 108-122

ISSN: 1771-2084

\section{Electronic reference}

Ratheesh Radhakrishnan, « Hamare Keral Mein Ek Kahavat Hai...: Remakes in Cinema and the Burdens on the "Translated Text" », Transtext(e)s Transcultures 跨文本跨文化 [Online], 1 | 2006, Online since 13 September 2009, connection on 19 April 2019. URL : http://journals.openedition.org/transtexts/189 DOI : 10.4000/transtexts.189 


\title{
Hamare Keral Mein Ek Kahavat Hai... : Remakes in Cinema and the Burdens on the "Translated Text" \\ BY Ratheesh Radhakrishnan
}

\begin{abstract}
The thought that constitutes this article arises from a seeming distinction between the metaphorical use of "translation" to mean a wide variety of human/ technological exchanges and translation as a practice. Even though an enterprise like mine might prima facie be disqualified by one undertaken by Umberto Eco who suggests that "...translation scholars should have at least one of the following experiences in life: translating, checking and editing translations, or being translated and working in close co-operation with their translators", as coming from a space outside of translation, I would like to venture into a discussion of translation to make an argument that the recent rethinking on the subject has made anyone who uses any form of language qualified to undertake an inquiry into the process that we call "translation". ${ }^{1}$ Here I refer as much to academic works that have tried to conceptualise translation as a process that goes beyond the linguistic domain as I do to the everyday uses to which the term is put. I do occupy the space that is opened up in this context as far as this paper is concerned, but I am also unsure of my own practice (in undertaking the following inquiry) in relation to it. What would it mean to agree with Eco, even if we think that the boundaries could be drawn differently?
\end{abstract}

Cet article est une réflexion sur la distinction apparente entre l'usage métaphorique du terme " traduction» pour désigner une immense variété d'échanges humains/technologiques et la traduction en tant qu'elle est une pratique. A première vue, la remarque suivante d'Umberto Eco semble disqualifier mon projet: « Les théoriciens de la traduction devraient faire au moins une des expériences suivantes: traduire, relire et éditer des traductions, ou être traduit et travailler en étroite collaboration avec ses traducteurs ». Bien qu'issu d'un champ d'étude extérieur à la traductologie je voudrais néanmoins me risquer à discuter de traduction car les nouvelles théories sur le sujet légitiment n'importe qui usant d'une forme de langage pour réfléchir sur ce processus que nous appelons «traduction». Je fais ici référence aux travaux académiques qui ont essayé de conceptualiser la traduction comme un processus qui dépasse le champ exclusivement linguistique, mais il est aussi question ici du sens de ce terme dans la vie quotidienne. J'occupe dans cet article l'espace ouvert par ce contexte, mais je doute aussi de ma propre pratique (en lançant cette recherche) par rapport à ce contexte. Que pourrait signifier d'être en accord avec les propos d'Eco tout en pensant que les frontières sont susceptibles d'être dessinées différemment.

1 Umberto Eco, Mouse or Rat? Translation as Negotiation, London, Weidenfeld \& Nicolson, 2003, p. 1. 
这篇文章的主要构思来自于两种层次的“翻译”在表面上的区别, 一种是对 “翻译” 的隐喻 性运用, 即大量的各种人文和技术交流; 另一种是作为实践的翻译。即使像我一样的想 法乍一看也会被Umberto Eco 持有的所否定, 他提出, “从事翻译的学者在生活中至少应该 有下面经历中的一种: 翻译、检查和编辑翻译, 或者是被翻译并与翻译他们作品的译者 密切合作。”作为翻译圈之外的人, 我斗胆触及有关翻译的讨论, 我认为, 当今关于这个 问题的反思已经使得运用任何形式的语言的任何人都有资格来对我们称之为 “翻译” 的 过程进行质询。在这里, 我是针对那些试图把翻译当作一种超越语言学范畴的过程来解 释的学术作品, 以及这一术语在日常生活中的应用。我确实处在这样一种位置上, 在本 文所涉及的语境中它是开放的, 但我对自己 (在进行下述质询中) 的实践也未必有把握。 即便我们认为其边界的划定可能会有所不同, 但赞成Eco会意味着什么?

This article attempts to foreground two issues. The first is to understand what happens when a text produced in one language/context is "translated" into another. The case in point is that of remakes in cinema. A remake, as opposed to a dubbed version which is the same film with dialogues rerecorded in a different language, is when a completely new film is shot based on an earlier film. This film could be in the same language or not. In popular writings on cinema, remaking is seen as an obvious expression of lack of creativity. Thus for example, one of the most populist criticisms about Kannada cinema is that it is full of remakes unlike Tamil, Telugu or Malayalam cinemas, which make "original" films. $\stackrel{2}{2}$ Nonetheless, remaking is accepted as a legitimate practice within the film industry. $\underline{3}$ Instances of remakes can be as bizarre as the Australian film Breaking Away (dir: Peter Yates; English/Italian/French, 1979) "influencing" the production of Jo Jeeta Wohi Sikander (dir: Mansoor Khan; Hindi, 1992) to be remade in Telugu as Thammudu (dir: P.A. Arun Prasad, 1999) as Badri in Tamil (dir: P.A. Arun Prasad, 2001) and as Yuvaraja in Kannada (dir: M.S. Ramesh, 2001). Still, in relation to arguments on originality in cinema, remakes are seen as the worst sin. But why just in cinema? What is lost in translation has always been a problem to people as diverse as Robert Frost who said "Poetry is what is lost in translation" in the early decades of twentieth century to Sophia Coppola, who titled her film Lost in Translation (USA Japan, 2003) in the early years of the twenty-first. ${ }^{4}$ In her analysis of French cinema's Hollywood remakes, Lucy Mazdon tries to complicate the picture by arguing against the concept of the original itself. - Discussing the dubbed versions of Hong Kong films circulating in Andhra Pradesh, S.V. Srinivas argues for the fact that much is gained by this act of translation. He argues that to make it viable for a local market a number of alterations/additions might be needed, which sometimes include a change in the title of the film. $\underline{6}$ If we agree that the political debates surrounding a film are crucial to our understanding of cinema, then probably Ek Chottisi Love Story (dir: Shashilal K. Nayar; Hindi, 2002) is a much more interesting film than A Short Film

2 The cinemas that are used as examples in the paper are the various regional industries in India. Hindi cinema is more or less seen by people in most parts of the country. Kannada, Tamil, Telugu and Malayalam are languages spoken in the four south Indian states: Karnataka, Tamil Nadu, Andhra Pradesh and Kerala respectively. 3 The article on remakes in the Encyclopedia of Hindi Cinema provides an overview of remaking practices in Hindi. See Saibal Chatterjee, "Remakes: The Influence of Other Cinemas" in Gulzar, Nihalani, Govind \& Saibal Chatterjee (eds.), Encyclopedia of Hindi Cinema, New Delhi \& Mumbai, Encyclopedia Britannica \& Popular Prakashan, 2003, pp. 440442. 4 American poet Robert Frost (1874-1963). 5 Lucy Mazdon, Encore Hollywood: Remaking French Cinema, London, British Film Institute, 2000. One of the examples Mazdon looks at is the Hollywood remake of the Nouvelle Vague classic Breathless by Jean Luc Goddard. This film, made of a number references to films from Hollywood, she would suggest, should also be seen as a remake, albeit a conscious one, 6 S.V. Srinivas, "Hong Kong action film in the Indian B Circuit" in Ashish Rajadhyaksha (ed.), Cinema, Culture industry and Political Societies- Inter Asia Cultural Studies, Volume 4, Number 1, April 2003, p. 55. 
About Love (dir: Krzysztof Kieslowski; Polish, 1988), the film on which the former is based. 7 It should nevertheless be mentioned that remaking is one of the most under researched areas in film studies, in India and abroad.

The texts under consideration here are two films:Aithe (dir: Yeleti Chandra Sekhar; Telugu, 2003) and its remake, Wanted (dir: Murali Nagavalli; Malayalam, 2004). At least two important questions emerge in the context of this enterprise:

What is it in Aithe that allows for this instance of remake where the Malayalam film industry can appropriate a narrative into its own universe ? Or, to put it differently, what are the elements in this film that appear to be intelligible for a different film industry ?

How is the Malayalam film industry making sense of this narrative and what embellishments are needed for it to be rendered a possible text in its own industrial/social context?

In trying to answer these questions, I would make a link between the dominant form of cinema (not the content per se) and the hegemony of the middle class in Kerala and would try to point to the rapid shifts that are happening in the last decade or so in both these spheres. ${ }^{8}$ This section depends on a series of hypotheses about Kerala's polity that demands further elaboration, which is outside the scope of the paper.

The second part of the article, which will be more along the lines of raising some complications and questions, will be an attempt to think through the first section and understand what cinema as technology does to the idea of translation as we understand it.

\title{
Malayalam Film industry-History, Context and the Crisis narrative
}

\begin{abstract}
Aithe was remade into Malayalam as Wanted at a time when the film industry in Kerala was said to be facing serious crisis. One might ask: when was any film industry, especially in India, not said to be in a crisis ? However, although it is true that one of the discourses that sustains the various film industries is a discourse of crisis, this time in Kerala it did take some concrete forms. The narrative of crisis was the familiar one: films were not succeeding in the box office, piracy was making cinema halls redundant, production costs were going up, television was destroying cinema by keeping the families (women) away from the cinema halls. One of the most vocal arguments that explained the crisis came from the film producers' organization, the Film Chamber. They argued that the reason for the crisis lay in the entrenched star system in Kerala and that the remuneration of the stars and their interference in decision-making about films, resulting in rocketing production costs, caused much of the problem. It was also suggested that stars, greedy for money, overexposed themselves on television and stage
\end{abstract}

\footnotetext{
7 The controversy about Ek Chottisi Lovestory arose when the lead actress Manisha Koirala accused the director Shashilal Nayar of using a body double and showing a couple of semi-nude sequences without her consent. For a collection of writings on the controversy see www.cscsarchive.org. For an interesting visual essay on the film and spectatorship see Kunal Sen, "The Worth of a Movie Ticket: Ek Chhotisi Love Story" in Ashish Rajadhyaksha (ed.), Cinema, Culture industry and Political Societies- Inter Asia Cultural Studies, Volume 4, Number 1, April, 2003. Lawrence Venuti does make a similar point about the translated version in the context of literature. The problem with his approach is that he would still hold onto an idea of fidelity, which he would claim needs additions for a "domestication" of the original. See Lawrence Venuti, The Translator's Invisibility: A History of Translation, London \& New York, Routledge, 1995, p. 18. 8 Kerala is a small stretch of land that lies along the south west coast of India, which became a political unit in 1956 merging two princely states Travancore and Cochin and the region of Malabar which had been under direct British colonial rule.
} 
shows and that the crisis could be resolved by putting an end to all this. All these arguments might seem a little banal and humdrum but these factors did stop all activity in Malayalam film industry for months. $\stackrel{9}{ }$ On the other side were the intellectuals inside the film industry like the scriptwriter/director/actor Sreenivasan (and some major stars) who argued that it was the lack of good films that accounted for all these problems. A number of writings on Malayalam cinema maintained that the kind of middlebrow cinema exemplified by the films of film-makers such as Bharathan and Padmarajan needs to be made to overcome what they thought was a creative impasse in Malayalam cinema. 10 This latter argument had a lot of popular currency as was evident from the numerous letters to the editor columns in film magazines.

Before coming to the moment of translation that we began with, we need to focus a little more on this argument about a "lack" in today's Malayalam cinema. What exactly is referred to, when it is said that the qualities that had defined Malayalam cinema in a particular way have changed?

Outside the state of Kerala, Malayalam cinema is usually known for two kinds of films- slow paced realist films and soft porn films. ${ }^{11}$ But inside the state, Malayalam cinema is neither of the two. The identity of Malayalam cinema is closely tied with the production of its ideal "Other" in Tamil cinema. The lumpen political nature attached to Tamil cinema is often projected as standing in for the evils of a particular kind of cinema that Malayalam cinema was supposed to be always apart from. Various kinds of excesses including the nexus between cinema and politics (four of the chief ministers of the state were from the films- three were stars and one a scriptwriter), the well-entrenched star system and the connected fan activities, and the apparent disinterest in any form of realism have been historically attached to Tamil cinema. ${ }^{12}$ The self-description of Malayalam cinema on the other hand included characteristics like its ability to tell stories, to make realist cinema without necessarily being slow paced and most important of all was that it was "family cinema". 13 Thus in the popular production of a Malayalam cinema inside Kerala it was the dissociation from both the lower classes (who are supposed to revel in the MGR/ Rajnikanth type of mass cinema) and the "fully formed citizens/viewers" of the film societies that was central. 14 Jenny Rowena has rightly argued

9 A strike, that stopped all production activities until the stars/actors signed a contract with them, was called by the producers and was in effect in the early months of 2004. 10 Both Bharathan and Padmarajan are Malayalam film-makers who started their careers in the 1970s and had a very successful stint tuntil their death in the early 1990s. The former a painter and the latter a short story writer and novelist were seen as the best examples of Malayalam realist cinema outside the art house circuit. Their films were successful at the box office also. Many of the articles that came out on Malayalam cinema suggested that their demise presents a crucial point in the end of a "golden era" in Malayalam cinema. For example see S. Saradakutty, "Vellithirayil Thee Padarna Kalam" (When the silver screen caught fire) in Mathrubhumi Weekly, June 12-18, 2005; N.P. Sajeesh, "Flawed visions: disrupted desires and debased sensibility" in http://www.kairalee.com/cineKairalee/flawed.htm ${ }^{11}$ Malayalam cinema, along with Bengali cinema, is known for its "good cinema" that has been recognized both by the Indian government (as seen in the yearly National Awards) and has been selected for international film festivals including Cannes. Adoor Gopalakrishnan, G Aravindan, John Abraham, Shaji N Karun and recently Murali Nair are names that are familiar to international film festivals. At the other extreme the industry is also known for producing soft porn films that have always had a market outside the state. 12 For an analysis of Tamil cinema see MSS Pandiyan, The Image Trap: MGR in Films and Politics, New Delhi, Sage, 1992 and Sara Dickey, Cinema and the Urban Poor in South India, New Delhi, Cambridge University Press, 1993. For a critical engagement with emergence of star excesses in South Indian (except Malayalam) cinema see M. Madhava Prasad, "Cine-Politics: On the Political Significance of Cinema in South India" in Journal of the Moving Image, No. 1, Autumn 1999. 13 The attempt at narrating the story of Malayalam cinema as "family cinema" has been done by erasing large chunks of films, stars. that do not fit into it. See Ratheesh Radhakrishnan, "Soft porn and the Anxieties of the Family: The Gendering of the Imagined Addressee of Malayalam Cinema" (Forthcoming), 2005. 14 Rajnikanth and MGR are two of the big stars in Tamil cinema with 
that the aversion that Malayalam cinema has often shown Tamil cinema is the displaced response to Dalit bodies and "sensibilities" within the region itself. 15 The production of a "family cinema" has gone hand in hand with this implicit othering of the lower classes/castes and the cleaning-up of the exhibition spaces has been part of the endeavour. 16 Upon closer observation, these qualities that are attributed to Malayalam cinema lose their neutrality, and their class and caste connotations get foregrounded. I argue that it is these "qualities" of Malayalam cinema that are being mourned by the many commentators on Malayalam cinema. I argue that the formal "qualities" of Malayalam cinema are strongly tied up with the hegemonic position that the middle class has enjoyed in Kerala.

Kerala's history ever since the imagination of the region as one single entity, is tied to the gradual production of a powerful middle class. ${ }^{17}$ This was effected in at least two steps: the first, the discursive eradication of caste as a political category and its replacement by class during the early days of the Communist Movement, and secondly, the take over of the left radical discourse by the service sector in the 1960s-70s. 18

The first move put in place "class" as the only framework in which any understanding of Kerala could take place. The ideals of the Communist movement had started circulating in Kerala as early as the mid-1920s. Although peasants and the workers, mostly from the lower castes, were being mobilized from the early 1930s, the official unit of the Communist party was formed (secretly) only in 1937. 19 The party had phenomenal success through the next couple of decades and was able to articulate a new politics- one that was based on classculminating in the historical victory in the first general elections in the state in 1957 and in the dismissal of the first ministry by the Congress-led Central government in 1959. The

\begin{abstract}
a mass following which includes a number of fan clubs. On the other hand, the film society movement was one that was started in the mid- $20^{\text {th }}$ century for circulation of classics from Europe and other parts of Asia. The popular notions that I am referring to are not the recent academic writing on Kerala and the perceptions of intellectuals here. The focus on notions like "family cinema" and middle cinema has been the most popular perception as evident from film magazines and film criticism over the years, 15 Jenny Rowena, "Malayalacinemayude Nanma" The Virtues of Malayalam cinema], Unpublished, 2002. 16 Witness the Crown cinema in Calicut where the noon shows are adult films and evening shows are all Hollywood classics/blockbusters. The time when you are seen near that cinema used to be an issue until recently. The common language used to describe the soft porn cinema halls was that of hygiene. The cleaning-up of the cinema has a longer history, especially in Hollywood. It was in the wake of a perceived threat of mobilization of immigrant labourers and women that an active cleaning-up drive was initiated in America and Germany in the 1920s and the 1930s. Cleaning-up of cinema halls was also a narrative clean-up which instituted the famed "Hollywood realism" that gave us those classics. For discussions on early cinema and cleaning-up drives see Tom Gunning, "The Cinema of Attractions: Early Film, its Spectator and the Avant-Grade" in Thomas Elsaesser, Adam Barker (eds.), Early Cinema: Space-Frame-Narrative, London, British Film Institute, 1990. Miriam Hansen, "Early Cinema - Whose Public Sphere ?" in Thomas Elsaesser, Adam Barker (eds.), Early Cinema: Space - Frame - Narrative, London, British Film Institute, 1990; and for a discussion on similar lines about Madras, see Stephen P Hughes, "Policing Silent Film Exhibition in Colonial South India" in Ravi Vasudevan (ed.), Making Meaning in Indian Cinema, New Delhi, Oxford University Press. 2000. 17 As mentioned, the formation of the Kerala state happened in 1956. But the imagination of a region as defined by the language Malayalam precedes this by many decades. 18 Caste refers to a system of social stratification that exists in India. In this system individuals are born into one of the castes usually defined by their hereditary occupation. The hierarchies related to caste still survive to this day though it has had tremendous changes through the ages. 19 For a discussion on the historical background of the birth of Communism in Kerala, see Robin Jeffrey, "Matriliny, Marxism and the Birth of the Communist Party in Kerala 1930-1940" in The Journal of Asian Studies, Vol. 38, No. 1, November 1978. Detalled accounts of the history of Communist Movement in Kerala see T.J. Nossitter, Communism in Kerala: A Study in Political Adaptation, New Delhi, Oxford University Press, 1982; Dilip M. Menon, Caste, Nationalism and Communism in South India: Malabar, 1900-1948, Cambridge, Cambridge University Press, 1994.
\end{abstract}


most significant development of this time is the discursive ordering of politics in relation to a framework of class. This also effected a marginalizing of politics based on caste, which was the central locus of modern politics in Kerala before the advent of the Communist Party. 20 This discursive reorganization has had a tremendous influence in the intellectual history of Kerala ever since.

The second move became possible when the service sector, capitalizing on the absence of a well-defined proletariat, took up a hegemonic position within Left discourse as the "revolutionary class". Though the attempts of the various ministries, especially those of the left, during the early years after state formation were directed towards industrialization (that it was by the invitation of the first Namboothiripad ministry that the industrialist giant, the Birla group came to Kerala to start the by now infamous Gwalior Rayons Factory is well known), they were abandoned by the late 1960s. ${ }^{21}$ It was this period that saw the recognition and the hegemonic surfacing of the service sector as constituting the future of Kerala's modernity though teaching and other service activities were highly respected right from the period of social reform of the later nineteenth and early twentieth centuries. In the wake of an economy that had no production base, this service sector middle class defined itself as the agency of development and functioned under the aegis of the modern state with its limited but significant promises of modernity. The emergence of the various "service sector organizations" like the Non-Gazetted Officers associations, Gazetted Officers associations, School and College Teachers associations, Bank Employees and Officers associations and the popular science movement, the Kerala Shasthra Sahithya Parishad, all contributed to a coup d'Etat of the political by the middle class in Kerala. 22 This situation then determined the only locus from which politics could be forcefully articulated: the location of a service sector middle class. The centrality of these organizations in the everyday politics of Kerala was selfevident for anyone following the developments in Kerala's polity. $\underline{23}$

I argue that the collapse of the middleclass-ness of the cinematic form and narrative and the fissures in the secured middle class nature of Kerala is the context that allows for the following thoughts on translation.

\section{Aithe and Wanted}

The two films under discussion obviously share a story, which is credited to different people. In the Telugu version the story and screenplay are credited to Yeleti Chandra Shekhar and in Malayalam the story is ascribed to Gangaraju (who is credited as being the producer and dialogue writer of the Telugu film) and the screenplay to Priyadarshan. The story goes like this:

\footnotetext{
20 The late nineteenth and early twentieth century in Kerala are marked by various caste-based movements both among the lower and the upper castes. The most important figures who are remembered as the torch bearers of Kerala's modernity, and like Sree Narayana Guru, Ayyankali, and V.T. Bhattathiripad were all working towards organizing their castes and towards social reform. 21 The polluting Gwalior Rayons factory in Mavoor near Calicut was closed down in 1999 following pollution-related protests from various groups who agitated for its closure for over 30 years. The company was formally shut down in 2001. 22 It is not just on the Left that that this has happened. It is my contention that the form of politics that $t$ Left, you will see an equivalent one in the Congress party 23 The significant shifts in Kerala's history will have to remain sketchy and hypothetical at this point of time. This is also due to the unavailability of research on the political history of modern Kerala.
} 
A powerful don in a big city in India in his urgency to escape to the Gulf hatches a plan, which would involve four young men living in a smaller town. The plan is to get these four men to hijack the flight that will be carrying the don and a minister, to get them to land in Katmandu and then to escape in the confusion resulting from the fact that the police have to rescue the minister. Paralleling this narrative, through constant intercuts, we are introduced to four young men, the protagonists of the film. These four are jobless middle class boys bearing a family burden, trying out various jobs unsuccessfully. At one point in the film the protagonists start discussing a plan that they are hatching to make money. This plan is supposedly to be executed on board a flight. We are given the impression that the four men about whom the don is talking and the protagonists are the same until they get into the same flight as the don and kidnap him before its takes off. Their plan is to hand him over to the police and take the reward. They chain him to a tree in a forest and with the help of their female friend, who is a medical student, try to hand him over to the police. Obviously it is not that simple. The local police chief is the don's man. But we are also introduced to another police officer who has been tracking the don for a long time and has now come to the city where the other events are taking place. Finally the don escapes the custody of the young men only for the police officer to catch him. When the friends have lost all hope of getting the money, the police officer, who knows everything that has happened, makes sure that they are rewarded.

Both these films use technology to its perfection while keeping the scale of the film to the minimum. The parallels with what are called the new multiplex movies are obvious. The absence of big stars in the lead role, the low budget, the attempt to tell a small and simple story have been identified as the characteristics of these films.

Aithe, which had a subtitle, "All films are not alike", could be seen as a film that anticipated the arrival of the first multiplex theater complex in Hyderabad: Prasad's. This film presented a new kind of aesthetic that addressed the new emerging upper class in Andhra Pradesh by presenting an alternative to the mass film or the star film. This was different from an earlier "class film" like Shankarabharanam (dir: K.Viswanath, 1979) or Sagarasagamam (dir: K. Viswanath, 1983), which used classical art forms like Carnatic music, or Bharatanatyam as its thematic in an attempt to lure an upper class/caste audience, in that it employed what has been called by Tejaswini Niranjana a "techno aesthetic" in the context of Mani Ratnam's Roja (Niranjana, 1994). ${ }^{24}$ Niranjana goes on to describe the character of Rishi Kumar played by the actor Arvind Swamy in Roja in terms of the representation of a new national-modern who is skeptical of the state. ${ }^{25}$ Aithe addresses such a new class, a class that has aspirations for a globalized existence with the development of the IT sector and the dot-com economy, without the burden of obvious "traditionalist" markers. ${ }^{26}$ The development of this class in the

\footnotetext{
24 A "class film", Srinivas writes, " situates itself in opposition to a mass-film and the subaltern public sphere formed around the genre and in the process mobilizes the support of the 'elite of the society' for a reformed popular cinema", in Fans and Stars: Production, Reception and Circulation of the Moving Image, Unpublished PhD Thesis. University of Hyderabad, 1997, p.114. Tejaswini Niranjana, "Interrogating whose Nation ? Tourists and Terrorists in Roja", Economic \& Political Weekly, Vol. 29 (3), January 15, 1994. 25 Roja is an important film in the history of Indian cinema for more than one reason. This film marked a radical shift in the use of technology of Indian cinema and introduced a new take on Indian nationalism in the context of emerging right wing nationalist movements and the liberalization of the economy. This film, which engendered a fierce debate in the pages of Economic \& Political Weekly following the above-mentioned article of Tejaswini Niranjana, is considered to be an important moment in the history of film studies in India as a we encounter it today. See Ravi Vasudevan, "Introduction" in Making Meaning in Indian Cinema, New Delhi, Oxford University Press, 2000, pp. 1-2. 26 Niranjana writes, "'Modernity' and 'tradition' come together unproblematically in/for the authentically secular new middle class (Hindu) subject who- marked as 'Indian'- has transcended communal difference just as s/he transcended caste, reserving the isolated second term 'tradition' for those who can then only be fundamentalist, communalist or casteist", Niranjana,
} 
urban centres in Andhra Pradesh, especially in Hyderabad, is coupled with the development of the Telugu community as one of the biggest Indian linguistic communities in the United States during the 1990s. ${ }^{27} \mathrm{It}$ is this section of the audience for whom the best option is a multiplex, which offers in addition to a menu of films, all possible avenues of consumption, in comparison to the regular old-fashioned cinema hall. Referring to multiplexes and the refurbishment drive carried out by cinema halls in Hyderabad, S.V. Srinivas writes:

often the attraction of the luxurious cinema hall for the middle class audience has been the reduced presence of the lower class viewers, no doubt affected by the pricing of the tickets. $\underline{28}$

This pitching of the film is what makes it inviting for a different industry to rework the film to suit its context, as it is possible to make an argument that the development or at least the imagining of such a class is underway in the bigger cities in India.

The Malayalam film retains the casting convention of the Telugu film by casting relatively unknown actors in the role of the protagonists and does maintain the high technical quality of the "original". This was accepted as a viable option after the recent success of the film 4 the People (dir: Jayaraj, 2004), which featured newcomers in the lead roles. ${ }^{29}$ At one level it follows from the debates of the time about the role of super stars in the film industry in Kerala, the demand to cut production costs and also from a general feeling that the towering presence of the super stars is not needed for a film's success. At another level this could be seen as the attempt of the filmic narratives to address the spectator as the globalized national-modern (in the Arvind Swamy sense) as it does, in very obvious ways try to emulate the recent experiments in Tamil cinema initiated by the films of Mani Ratnam and Shankar. ${ }^{30}$ Director Murali Nagavalli's suggestion in an interview to a film magazine that Wanted is not a "family film" but a "hi-tech film" and his comparisons of his film with Hollywood films (because of the absence of "unwanted elements" like the comedy track, for example) is significant in this context. 31

There were some crucial differences between the spate of films that came out in Malayalam after the success of 4 the People, and Wanted, and more crucially between Aithe and Wanted. Aithe attempted to address the youth in Kerala (mostly upper caste) by creating a new kind of narrative that presents the choices in a fast, globalizing world along the lines of the

"Interrogating whose Nation ? Tourists and Terrorists in Roja", 1994, p. 81. 27 Most websites mention Telugus as one of the biggest Non-Resident Indian populations in the United States, especially in the context of the boom in the software industry. For a detailed account of Telugu population in the United States, see T.L.S. Bhaskar, "Telugu Diaspora in the United States", http://202.41.85.100/sss/dsociology/oc6.pdf 28 S.V. Srinivas, "Of Couple Seats and Multiplexes" in Sephis Newsletter, No. 9, January, 2004, p. 8. 29 The success of this film, which even the same director could not repeat in his later film, could be attributed to the new aesthetic that the film tried to present based fully on technology and through its music. The assumption that such films, which were not embedded in the industry's history and location, would succeed backfired with a number of film-makers. 30 Tamil cinema had never had an audience outside Tamilnadu until Mani Ratnam made Roja and Shankar started making films, both in the early 1990s. Their films not only had narratives that attempted to deal with the nation but also succeeded outside the state. It is significant that in many of the new narratives in Malayalam cinema, the "national" seems to intrude into the local in a way comparable to the Mani Ratnam narratives. Examples other than Wanted would include the latest success Kazhcha (dir: Blessy, 2004) where a small Nair family in central Kerala is pushed into the national scene because of a boy who escaped from the earthquakes in Gujarat. 31 See "Wanted Kudumbachithramalla Hitech Chithramanu: Murali Nagavalli" in Nana Film Magazine, 15, August 2004, pp. 34-36. A comedy track is mostly a parallel narrative performed by comedians in a film, which might or might not have any connection with the main narratives. 
"original"and films like 4 the People. This was supplemented by an attempt at accounting for the history of the film industry by casting superstar Mohanlal in a guest role. $\underline{32}$ There are a number of directions the discussion about this instance of remaking can take, including the appearance of Hyderabad as a city that harbours both the underworld and the Non-Resident Malayalee (the "other" city in the Telugu version is good old Mumbai), the representations of Cochin and the local underworld, the change in the caste identity of some of the characters and so on. But I would like to restrict this article to examining just one aspect of the remade film. That is the one I just mentioned, what is Mohanlal doing in a film that is the remake of a Telugu film that did not have any stars in it?

One of the obvious answers to the question is that in many cases new narratives give birth to new stars under the aegis of the reigning star. This has been one of the uses that many film industries have made of an aging star as in the case of Marlon Brando's guest appearance as Superman's father in the first film featuring the super hero, Superman: The Movie (dir: Richard Donner, 1978), or Amitabh Bachan in epic narratives in Hindi such as Kabhie Khushi Kabhie Gham (dir: Karan Johar, 2001). The star in Wanted, both in relation to what is signified by the image of Mohanlal on screen and by the character he plays in the film, has to be the role model to the new heroes or the pre-history to the narrative at hand. $\frac{33}{3}$ Thus Mohanlal as the police officer, a Non-Resident Malayalee, albeit being in a guest appearance (27 shots to be precise), becomes the quasi-hero of the film. In the Telugu version a relatively unknown young actor Sivaji Raja plays this role. Mohanlal seems to have a sober wardrobe in the film, mostly appearing in short-sleeved light coloured shirts, not tucked in, and dark coloured trousers that give a sense of authority to him, whereas Sivaji Raja appears in T-shirts and jeans and is more colourful and appears to be slightly eccentric. The ending of the film helps us in seeing the real significance of the casting. In the Telugu version, the police officer who has been given the reward for catching the don leaves the bag full of money at the place where the young guys live and informs them on the phone about it. But in the Malayalam film, the police officer now played by Mohanlal calls them into the police headquarters and with a lot of ceremony hands over the money in the presence of the Inspector General of Police and recommends that one of the youngsters be given a job with the police. The logic of handing over takes larger proportions in relation to the stature of the actor performing the role. Mohanlal as a sign that signifies a character "created by Gangaraju" could take on meanings well beyond the scope of the original instance. If in language one would go on to look at the various signifiers that the word on the page could have meant to understand the complex nature of translation, in our case we will have to look at what Mohanlal signifies in the visual universe of the Malayalee. What does Mohanlal mean to the Malayalee audience today?

Mohanlal, alongside Mammooty, the other big star in Malayalam, exemplified the best of the Malayalee middleclass-ness in the 1980s in Malayalam cinema. ${ }^{34}$ Where as Mammooty donned the roles of authoritative big brother or husband in most of his films, Mohanlal came

\footnotetext{
32 Mohanlal is one of the two reigning stars in Malayalam cinema. He started his career in the early 80s and has been considered a major since the late 1980s. 33 The Telugu film was also doing something similar when they invited the biggest star in Andhra Pradesh Chiranjeevi as the chief guest for the 100th day celebration of the film. 34 Mohanlal has received more attention than Mammooty from academia. To name some of the recent writings: T. Muraleedharan's work on male bonding in Mohanlal films: "Disrupted Desires: Male bond in Mohanlal films", Deep Focus Film Quarterly, Vol. IX, No. 1, 2001; S. Sanjeev and C.S. Venkiteshwaran on the issues of caste in relation to Mohanlal-Sreenivasan films: "Sreenivasan", Re-Vision, March 2002, and Ratheesh Radhakrishnan's work on the star/fan films of Mohanlal: "'Looking' at Mohanlal: Spectatorial Ordering and the Emergence of the 'Fan' in Malayalam Cinema", Deep Focus Film Quarterly, December 2002.
} 
to occupy the role of the "common man" with his films like the comedy T.P. Balagopalan MA (dir: Sathyan Anthikkad, 1986), the tragedy Kireedom (dir: Sibi Malayil, 1989) and even with action films like Irupatham Noottandu (dir: K Madhu, 1987). These films also exemplified the middleclass-ness of the Malayalam cinema in ways that were discussed earlier in the paper. $\frac{35}{}$ Starting with Devasuram (dir: IV Sasi, 1993) Mohanlal acted in a number of films that went contrary to his image as a common man. He was seen to take on superhuman characters to play and was criticized for emulating Rajnikanth. ${ }^{36}$ With a series of films during the period from 1997 to the present, Mohanlal was seen as following a pattern that was best fit for the Tamil industry. The Mohanlal fans' association became visible at the same time adding to the argument that there was a lumpenization of Malayalam cinema that was being put in place..$^{\frac{37}{}}$ Another development in the career of Mohanlal that was taking place at the same time went unnoticed. This was the fact that the above-mentioned re-signification of Mohanlal was just one part of a split that happened in the singular way, as the middle class guy next door, in which the signifier Mohanlal used to function. The second avatar of Mohanlal, which has not been noted by many commentators on Malayalam cinema, was as the "high cultural" icon of Kerala. In 2001, Mohanlal acted for the first time in his career in a play, Karnabharam, in Sanskrit directed by Kavalam Narayana Panikker, which won a lot of appreciation in theatre festivals all over India, especially at the National School of Drama (NSD) in New Delhi and then did a solo performance entitled Kathayattam directed by T.K. Rajeev Kumar featuring the most famous characters from Malayalam literature. He also acted in a Hindi film, Company (dir: Ramgopal Varma 2002). He produced and acted in the role of a Kathakali actor in Vanaprastham (dir: Shaji N Karun, 1999), an art-house film which was an Indo-French co-production and was shown at the Cannes Film Festival. His interest in antiques gained a lot of publicity during the same period when he got Artist Namboothiri, a well-known illustrator/sculptor to do a mural in his house. Outside of his film career Mohanlal also emerged as a model entrepreneur for a non-industrial state like Kerala by opening a chain of restaurants abroad, an international school in Trivandrum, "Visual Magic"(a television production company with plans to make animation films and DVDs of plays like Karnabharam), a food processing plant and "Vismaya", a Film studio. ${ }^{38}$ Here we see a different Mohanlal emerge at the same time that he was being "lower classed". This is a Mohanlal who can aspire to exist in a new conception of the Malayalee nation both as a cultural figure through his Sanskrit plays and his film screened at Cannes, and as a businessman who can effectively globalize at the right time.

The split in the sign Mohanlal, I argue, gives us a clue to the split in the singular middleclass-

35 In the above-mentioned article, C.S. Venkiteshwaran and S. Sanjeev have demonstrated the caste-ing of these seemingly casteless middle-class hero characters played by Mohanlal during this period. 36 This suggestion was heard for the first time when the film Narasimham (dir: Shaji Kailas, 2000) was released. On more than one occasion in the film, a lion was shown immediately after Mohanlal's close-up shots, thus equating the powers of the two. This was seen as a very "Tamil cinema" (specifically associated with Rajnikanth) mode of filmmaking. $37 \mathrm{~A}$ discussion on the issue of lumpenization in relationship to stardom could be seen in S.V. Srinivas, Fans and Stars: Production, Reception and Circulation of the Moving Image, 1997, and with special reference to Mohanlal, in Ratheesh Radhakrishnan, "'Looking' at Mohanlal: Spectatorial Ordering and the Emergence of the 'Fan' in Malayalam Cinema", 2002. The decrying of Malayalam cinema's quality had another object that emerged at the same time. This was a spate of soft porn films, which saw the emergence of another star, Shakeela. 38 Mohanlal has always been involved in business ventures outside cinema. The most important among them was a seafood export business. But it was in collaboration with another businessman who fronted the venture. What I am referring to is the emergence of Mohanlal as a visible figure in this field. The various advertisements in which Mohanlal appeared at this time were also imbued with parochialism. This needless to say, is a new parochialism that is packaged for a global audience. 
ness that we identified as the feature of both the identity of the dominant audience of Malayalam cinema and of the form of cinema itself. As for middleclass-ness of Kerala society, I would like to argue that unlike the popular perception that the middleclass-ness is getting more and more entrenched, it is a fact that the last couple of years has witnessed a set of developments that has unsettled the middle class Malayalee. The 32-day long strike of Government Employees protesting against the possible cut in their benefits in 2002 which ended without success, the recent attacks on Bank officials after the suicide of a Dalit girl who was refused educational loan, the emergence of an employment contract system (an example being the standard contract under which post graduates are inducted in colleges as guest lecturers paid on an hourly basis) and the burning 'protection' problem of school teachers; these could be seen as the visible forms that the crisis, which has been underway for some time, has taken in the recent times. This has, I argue, resulted in a split in the middle class in Kerala where it has become imperative for them to look for new forms of subsistence. One section of the middle class, has tried to deal with this crisis by globalizing itself, whereas another section is fast being left behind. Even the recent "theoretical struggle" in the Kerala segment of the Communist Party of India-Marxist (CPI-M) regarding the political position visà-vis globalization and development funding from international donor agencies, could be read as a tussle between two sections who have newer aspirations unlike before in the context of the above-mentioned break in the middle class. It is not surprising to note that the split in the sign Mohanlal, which tries to address both segments of the audience through his different personae, can be used as a metaphor for the segmentation of the Malayalee middle class. . $^{39}$ The dominant middle class in Kerala, I argue, has bifurcated into one section which has the cultural capital (caste identity playing an important role in this) to globalize itself and keep its hegemonic status whereas another section which is still holding on to an earlier economy is falling behind. Discussing the impact of globalization on middle class in India, Satish Deshpande observes that " there is one class for whom the benefits of globalization seems to outweigh the costs, it is the middle class, particularly its upper (managerial-professional) segment. [...] Having consolidated its social, economic and political standing on the basis of the developmental state, this group is now ready to kick it away as the ladder it no longer needs." 40 It is also because of such a context, let me add, that caste could be re-inscribed as a political question again in Kerala. 41

Paralleling Mohanlal's latter avatar, I argue, the Non-Resident entrepreneurial Malayalee, successful through his attachment to the emergent national economy since the 1960s, makes a discursive comeback to the imaginary space of the Malayalee nation. It is important to note that a sizable number of the people who had made this move in the 1960s were of the dominant caste of Nairs. This also coincides with the disappearance of the Gulf Malayalee, especially of the lower/middle classes, an important figure in the 1980s, from both cinematic and regional narratives. ${ }^{42}$ The triumph of Malayalees outside the state was first noted by, significantly, the Hindi film Company. With Mohanlal's heavily accented but confident Hindi (the

\footnotetext{
39 The recent commercial success of a film like Natturajavu (dir: Shaji Kailas 2004), which was released after the release of Wanted shows that the "Mohanlal as Rajnikanth" films still have their audience. The irritation that is shown by a section of the audience towards such star films of Mohanlal points to their class location. 40 Satish Deshpand, "The Centrality of the Middle Class" in Contemporary India: A Sociological View. New Delhi, Viking, 2003, p. 150. 41 Obviously there are other important factors including the strength that the Dalit movement has acquired in the last decade and the considerable strides made on the political front in the country that has contributed to this. 42 The discussions about the NRM (or NRK) in contemporary Kerala include the successful industrialist mostly in America and Germany, and a few successful industrialists from the Gulf and from the metropolis in India. The generic city Bombay has given way to real cities like Bangalore and Hyderabad. The earlier Malayalee nation included the guy in the Gulf who was the harbinger of Kerala's development.
} 
kind that used to be a joke in old Hindi films) being accepted, the Malayalee pronounced his arrival on the national scene. The high point of the reaffirmation of the "cultural" Malayalee in the national space happens when Mohanlal in the role of Mumbai Joint Police Commissioner Veerapalli Sreenivasan in Company says:

Hamare Keral mein ek kahavat hai ki che mahine mil julneke baad yeh woh ho jata hai or woh yeh. [There is a saying in our Kerala that if you live closely with someone for six months, you will become him and him you.]

The Police Officer Narayana Swamy in Wanted follows this logic completely. ${ }^{43} \mathrm{He}$ is an uppercaste Malayalee settled outside of Kerala (his wife keeps on calling him back and at the end of the film he indeed goes back) who comes to the state to reaffirm his linkages with the youth and to perform the success of the globalized.

Thus in Wanted, the casting of Mohanlal signals to the narrative logic by which Malayalam cinema is trying to deal with a certain development in the polity; a change that signals the death of a hegemonic middleclass and the birth of a dominant upper middle class defined by its potential to globalize itself. The significance of the film is that, unlike the positions favoring "originality" would want it, it is a "copy" that has succeeded in effectively working out a narrative that accounts in its own way for a historical moment. Unwittingly and without really producing a story about any of the social churnings at hand, the film does provide us with an insight into the workings of contemporary Kerala society through its form and through modes of signification which, let me submit, are unique to the technology. It is also an important fact that it is by a simple act of casting that the narrative has attempted this.

The film tells us the reasons for the crisis in industry by narrativizing the fissures in the dominant form of Malayalam cinema and in the class formations in the state by strongly foregrounding its "ideal addressee" in the newly mobile segment of Kerala society. In this context, I would like to make my contribution to the debate on the crisis in the industry derived exclusively from the reading of this film. Disagreeing with both the dominant positions on the crisis- the problems with production, piracy, television on one hand and the problems with narratives on the other - I suggest that the crisis in the Malayalam film industry is a crisis of distribution. Unlike a Malayalam cinema that could account for its "internationalism" in the 1980s by releasing videocassettes of new films in the Gulf simultaneously with its theatrical release in Kerala (who would not remember those films we saw with English and Arabic subtitles), the industry today has not extended its market beyond the traditional theatrical space. The DVD/VCD industry has not yet taken off in the case of Malayalam cinema like it has in say Tamil or Telugu sectors. ${ }^{44}$ The inability of the industry to recognize the new imaginations of the Malayalee nation in its distribution sector and the inability to put in place exhibition set-ups like the multiplexes for such films inside Kerala itself, even when it has ways to account for it in narrative terms, is its crisis. The connection between the closing down of cinema halls in Kerala (440 in 8 years of which 217 were closed down after the year 2000) and the narrative reorganization that might be happening in Malayalam

43 The comparisons made between Mohanlal's roles in Company and in Wanted, I suggest is not because of the similarity in the roles but in the similarity of location. The internet is full of reviews of the latter making this link. 44 The immediate availability of Tamil cinema DVDs in countries like Malaysia, Sri Lanka etc. is a case in point. The Tamil industry has seen the potential of the overseas market a very long time ago. Telugu industry which rose to its call late have made solid advances in the field. Here again the proliferation of pirated VCDs of Malayalam films should be separated out from my argument. What I am talking about is the inability of the industry to take over that space. 
cinema seems to have missed the eyes of the industry. ${ }^{45}$ Wanted is not necessarily the only film that has tried to narratively deal with the problem. Other films like Aparichithan (dir: Sanjeev Sivan 2004), which staged the comeback of one of most internationally successful Malayalee, Santosh Sivan, the cinematographer (who also directed among other things, the breathtakingly techno-savvy promo for Kerala tourism), and had Mammooty playing a wild life photographer of the National Geographic Channel based in the US on an assignment in Kerala, do signal the emergence of the global Malayalee. Wanted, I suggest, could produce the global Malayalee and could place him vis-à-vis the protagonists in the film whose aspirations it could effectively represent.

\section{Remaking cinema as an act of translation?}

Thus the remade text, far from being a pale copy of the original makes significant strides in accounting for the industrial and cultural/political context that it is entering. Disagreeing with Walter Benjamin's understanding on translation that emerges from his description of a bad translation that "while content and language form a certain unity in the original, ..., the language of the translation envelopes its content like a royal robe with ample folds" and his definition of a "real translation" that it is (ought to be) " transparent; it does not cover the original", let me argue that if we are able to think of the translated text as having to deal with its own context rather than the context of the original, the new language/context presents the possibility of radically refashioning the content itself. ${ }^{46}$ Cinema as an image-making technology presents us with an excellent instance to examine this argument. Even in the case of a literary translation that shows "fidelity" to the "original", an inquiry into the discursive conditions that makes possible the act of translation and the context of its appearance/ publication would allow us to frame the former in terms that are completely separate from the latter. What more does the refashioning of the cinematic image, which the remaking process has to account for, tell us about translation ? Does it allow us to theoretically dismantle the many "centres" like the author or the translator on which most discussions of translation are based? What does such a decentering do to the very idea of translation itself in a situation where the agency of the translator (not to mention the author) looms large ?

The author in relation to cinema has been a cause of confusion. Though it has tried to retain the romantic notion of the author that comes from literature, in the figure of the director, this has not been an easy argument to make. One of the closely guarded secrets of the English Literature classroom has been that it is the same period that saw the Romantic Movement in literature in Europe that saw the development of private property and copyright laws. ${ }^{47}$ The authorial presence in the law closely follows the romantic conception of the artist. Cinema and before that photography has created a break in this link because these "art forms" are made through technological interference. In the case of cinema it is plain private property logic that is at work. Author or not, the ownership of films does not lie with the director: it is the producer who owns it. The emergence of the author as the "supervising authority" in

\footnotetext{
45 As mentioned by Prem Chand in his column Noise in Chithrabhumi Film magazine, July 11, 2004. 46 Walter Benjamin, "The Task of the Translator" in I/luminations (Trans: Harry Zohn), Glasgow, Fontana \& Collins, 1970,1979, p. 75, p. 79. 47 Lawrence Liang, "The Ghost in the Machine: The Legal Capture of Technology" in Sarai Reader: Shaping Technologies, New Delhi, The New Media Initiative \& Centre for Study of Developing Societies, 2003.
} 
Indian cinema has been in the context of an argument for censorship in Justice Hidayatullah's judgment of the case against political censorship filed by the filmmaker K.A. Abbas, as noted by Ashish Rajadhyaksha. $\frac{48}{}$

The legal debate over the ownership of film has been a historically important one with both parties having different levels of success in different countries. ${ }^{49} \mathrm{It}$ is then not an accident that in the list of copyright infringements in Indian Copyright Act of 1957, translation of a literary text is featured where as the remaking of cinema is absent. To that extent, in the context of the Act, remake rights in cinema cannot not given by the director or the scenarist but by the producer, unlike in literature where the right holder is the writer. ${ }^{50}$ Also you could potentially remake a film that is copyrighted in the name of an individual or an organization and have legal arguments of "originality" that is not possible with a literary translation. ${ }^{51} \mathrm{To}$ take the example of Aithe and Wanted, the question of who is the author becomes an issue in the case of the former and who is the translator becomes an issue in the case of the latter. It becomes an extremely confusing issue if we assume the first process is the inter-semiotic translation which involves an original story, as the credit for the story for the Malayalam version is given to Gangaraju, the producer/dialogue writer of the Telugu version, whereas the Telugu version has the director Yeleti Chandra Shekhar credited with story ! And now, what about the "original text" ? Where does one start looking for an original ? Is it the story, in which case the Telugu film text becomes less important, is it the screenplay on which Aithe is based, or is it the film Aithe itself? In legal terms the original of a film is its "original print" and not the narrative or the idea behind it. Though the various people involved in the making of the film do hold the right to their part of the work (e.g. music composers holding the copyright for the score), but their status in relation to the film text and authorship remains unresolved. And further, if we were to argue following the discussion on the remaking of Aithe into Wanted, that the star, in this case Mohanlal, can claim authorial status as he seems to contribute a whole semiotic universe to the text, bringing a whole range of discourses along with him in ways hitherto unnoticed, then where does the issue of authorial rights end ? 52

Even "translating" this discussion into the ambit of translation theory and the discipline of Translation Studies posits issues. If we start with the story of the film we are talking about an inter-semiotic transfer and if we start with the film we are talking about cinematic translation. The absence of the translator figure, I suggest would create some anxiety for a discipline like Translation Studies that seems to be based by default on a tangible practice. This is an issue of some consequence as even in the cultural questions in this field, like the discussions of power relations in translation during colonialism or the politics of translation in the context

\footnotetext{
48 Rajadhyaksha argues that the idea that a socially responsible author could be made accountable for the meanings in a film was put in place by this judgment. Thus a Govind Nihalani or a Shekhar Kapoor will escape the censor because they "are", due to their status as art house filmmakers, socially responsible, Ashish Rajadhyaksha, "You can See without Looking: Reconsidering Freedom of Expression in the Cinema", Journal of the Moving Image, No. 1 , Autumn, 1999, p. 73. 49 Marjut Salokannel, "Film Authorship in the Changing Audio-Visual Environment" in Brad Sherman \& Alain Strawell (eds.), Of Authors and Origins: Essays on Copyright Law, Oxford, Clarindon Press, 1994, p. 69.50 in Chapter 1 of the Indian Copyright Act of 1957, the "author" who is the primary holder of copyright is defined as "in relation to a literary or dramatic work, the author of the work" and "in relation to a cinematograph film or sound recording, the producer". 50 This is also aided by the fact that what is protected in the copyright laws is not the 'idea' but the form in which the idea is put. And further, the test that is used to determine originality is to list out the difference between the texts rather than the similarities. 52 The star's claim to authorial rights could seem farfetched. But the Hindi star Dev Anand had tried to argue for rights over a film claiming that his performance should be copyrighted to him. Though the effort was unsuccessful to the extent that the court saw no labour involved in performance, this does raise interesting issues. See Dev Anand vs. Fortune Films, 1970.
} 
of imagining the modern Indian nation, there has always been the implied agency that is under discussion. ${ }^{53}$ Andre Lefevere, who argues that linguistic transfer "...should neither be equated nor confused with the wider cluster of problems associated with "translation" or 'translation studies'", does not suggest a way out of that possible collapse when he goes on to concentrate only on translation as practice. ${ }^{54}$ On the other hand Lawrence Venuti's attempt to "make the translator more visible so as to resist and change the conditions under which translation is theorized and practiced today" ends up attempting to argue for the "author" status for the translator when he suggests with regret, "in copyright law, the translator is and is not an author." ${ }_{55}^{5} \mathrm{At}$ a time when a significant Indian volume of translation theory defends its stress on theory by suggesting that "...tomorrow, a subtler and more sophisticated understanding of what constitutes 'good' translation will result from the fact of its being studied in a disciplined fashion", the question of what constitutes the object of translation studies becomes more pertinent. ${ }^{56}$ The recent volumes on caste and desire brought out by Katha uses the metaphor of translation without reference to any of the centres of translation like the source, the destination or even the author. ${ }^{57}$

Drawing from cinema where the various centres that determine the practice of translation are visibly under question, how does one start talking about the process of translation other than in terms of textual analysis of the kind I have done above ? This textual analysis, I submit need not be the one that we are familiar from literature- one that valorizes the text. Rather than explaining the text using the context, let us attempt to explain the context using the text; the text after all might just be an occasion for understanding the "context". The challenge in this attempt is to overcome the mode of straightforward content analysis when we deal with technologies like the cinema, and to attend to more complex issues related to signification and form. $\frac{58}{2}$

53 See Tejaswini Niranjana, Siting Translation: History, Post-structuralism and the Colonial Context, Berkeley, Los Angeles \& Oxford, University of California Press, 1992 and Aijaz Ahmad, " 'Indian Literature': Notes Towards the Definition of a Category" in In Theory: Classes, Nations, Literatures, Mumbai, Oxford University Press, 1994. 54 Andre Lefevere, "Composing the Other" in Basnett, Susan \& Harish Trivedi (eds.) Postcolonial Translation: Theory \& Practice, London \& New York, Routledge, 1999, p. 75. 55 Lawrence Venuti, The Translator's Invisibility: A History of Translation, London \& New York, Routledge, 1995, p.17, p. 9.56 Rukmini Bhaya Nair, "Introduction" in Translation, Text and Theory: The Paradigm of India, New Delhi, Thousand Oaks \& London, Sage Publications, 2002, p. 17. 57 See Tapan Basu, Translating Caste, New Delhi, Katha, 2002 and Brinda Bose, Translating Desire: The Politics of Gender and Culture in India, New Delhi, Katha, 2002, 58 This paper was presented at the conference "Translation, Culture, Interpretation: Issues and Trends" held at the Indian Institute of Technology (Bombay) in December 2004. 